BULLETIN Bulletin hispanique

HispaniQuE Université Michel de Montaigne Bordeaux

121-1 | 2019

La épica en el mundo hispánico (Siglo de Oro)

\title{
Fernando Villalón, Islas del Guadalquivir (Antología poética). Edición de Jacques ISSOREL
}

Sevilla, Renacimiento, 2018

Francisco Javier Díez de Revenga

\section{CpenEdition}

Journals

Edición electrónica

URL: https://journals.openedition.org/bulletinhispanique/8244

DOI: 10.4000 /bulletinhispanique.8244

ISSN: 1775-3821

Editor

Presses universitaires de Bordeaux

Edición impresa

Fecha de publicación: 24 junio 2019

Paginación: 386-388

ISBN: $979-10-300-0363-5$

ISSN: 0007-4640

Referencia electrónica

Francisco Javier Díez de Revenga, «Fernando Villalón, Islas del Guadalquivir (Antología poética). Edición de Jacques issorel», Bulletin hispanique [En línea], 121-1 | 2019, Publicado el 30 junio 2018, consultado el 02 enero 2023. URL: http://journals.openedition.org/bulletinhispanique/8244 ; DOI: https://doi.org/ 10.4000/bulletinhispanique.8244

Este documento fue generado automáticamente el 2 enero 2023.

All rights reserved 


\section{Fernando Villalón, Islas del Guadalquivir (Antología poética). Edición de Jacques ISSOREL}

Sevilla, Renacimiento, 2018

Francisco Javier Díez de Revenga

\section{REFERENCIA}

Fernando Villalón, Islas del Guadalquivir (Antología poética). Edición de Jacques ISSOREL, Sevilla, Renacimiento, 2018, 308 p. (col. Antologías, 105).

1 Una buena oportunidad para volver a leer la obra de Fernando Villalón la constituye esta selección de sus mejores poemas, que acaba de publicar, en su ya veterana colección de antologías de poetas, la editorial Renacimiento en Sevilla, tanto por los poemas que en ella se recogen como por el excelente estudio preliminar que lleva a cabo el hispanista Jacques Issorel, el mejor conocedor de la obra de Villalón desde hace muchos años, ya que sus trabajos sobre el poeta son de obligada referencia desde su tesis doctoral, Fernando Villalón ou la rébellion de l'automne. Un poète andalou de la génération de 1927 (1988), así como a partir de sus ediciones de los libros del poeta, tanto los publicados en vida como numerosos inéditos, hasta culminar en la publicación de sus Poesías completas (1998).

2 Se pone de relieve una vez más, a través de esta antología, la extraordinaria personalidad de Fernando Villalón (Sevilla, 1881-Madrid, 1930), conde de Miraflores de los Ángeles, cuya ocupación más importante en esta vida fue la de ganadero de toros bravos, profesión en la que intentó, como bien relata Jacques Issorel, hacer realidad su ideal de criar toros especialmente agresivos y temibles, como aquellos toros que asolaron las plazas en la época de los toreros míticos de principios del siglo XIX Pedro Romero o Pepe-Hillo, pero que en su tiempo no eran los astados que preferían las grandes figuras del toreo, como Juan Belmonte, más inclinados por el toro dominable 
que les permitiera realizar una faena artística y brillante que atrajese al público sin mucha tragedia.

3 Fracasó en su proyecto y se arruinó, y lo que perdió el ganadero, lo ganó el poeta, como indica Issorel. Villalón había reunido una amplia propiedad en terrenos de las marismas del Guadalquivir y los años que dedicó al campo en Andalucía la Baja antes de su ruina, le familiarizaron con la tierra y con el paisaje, con las historias, las tradiciones y las leyendas, con las canciones del pueblo. Todo ello y su amada Sevilla natal crearon el ambiente apropiado para que Villalón comenzase a escribir poesía y crease, poco a poco, una de las líricas más interesantes y originales de su tiempo, justamente en una época en la que estaba triunfando la promoción más prometedora de la poesía española del siglo XX, la «joven literatura», conocida posteriormente como la generación poética del 27. Con sus poetas Villalón tuvo intensa y activa relación en los últimos años de su vida, desde abril de 1927, cuando conoce a Gerardo Diego en la feria de Sevilla a la que acudió invitado por Ignacio Sánchez Mejías; y desde diciembre de aquel año, cuando se lleva a cabo el famoso homenaje a don Luis de Góngora en la Sociedad Económica de Amigos del País de la capital andaluza, donde comparte esos días con todos los poetas allí reunidos, especialmente con Federico García Lorca y Rafael Alberti, tal como este último relata en La arboleda perdida.

4 Nueva oportunidad pues para releer al poeta que surgió en los años centrales de la generación del 27, aunque el ser algo mayor y coetáneo de Juan Ramón Jiménez (nacidos ambos en 1881) y su temprana muerte no le permitieron seguir el camino de proximidad a los poetas del 27 que se evidencia en la intensa relación que tuvo en los pocos años en que coincidió en este mundo con ellos. Gerardo Diego lo incluye en su célebre y determinante Antología de 1932 porque consideraba que formaba parte de la nueva generación y para ello construye su «Poética» extrayendo, de algunas de sus cartas, el concepto que de la poesía tenía Villalón, muy relacionado desde luego con la de otros poetas presentes en la recopilación antológica. Y es que, como ellos, transitó por las etapas canónicas del grupo: neopopularismo, gongorismo y surrealismo, advertible este último en los textos experimentales, que ahora recoge con total acierto Jacques Issorel. Todo bastante alejado del concepto de poeta regionalista andaluz que, en principio, se atribuyó muy erróneamente a su compleja personalidad literaria.

5 La antología preparada por Issorel da muy buena cuenta de esta poesía tan reveladora, ya que recoge una buena representación muy adecuada de los tres libros que publicó en vida: Andalucía la Baja, de 1926; La Toriada, de 1928; y Romances del 800, de 1929, junto a algunos de los numerosos poemas que permanecieron inéditos tras la muerte del poeta durante muchos años, hasta 1985. Decisiva importancia tiene también aquí la presencia de la compleja y extraordinaria cosmogonía, «Kaos», y de algunos de los poemas más logrados que reflejan bien las distintas modalidades cultivadas por el poeta: neopopulares, humorísticas, ecologistas, espirituales y hasta surrealistas.

6 Hay que destacar, del mismo modo, que Issorel acompaña los poemas de una generosa anotación de los mismos que figura al final del volumen, en la que explica y aclara pormenores de carácter histórico, literario o léxico de numerosas expresiones del poeta que podrían ser difíciles de entender. Sobresale en este aspecto la presencia de las hablas populares especialmente del caló, utilizado por Villalón con tanta frecuencia como naturalidad en algunas de sus composiciones más próximas al acervo popular.

7 Interesa mucho el estudio preliminar de Issorel porque sintetiza certeramente el significado del poeta y su aportación a la poesía española del siglo XX. Destaca su 
reflexión sobre el sentido de la libertad que Villalón siempre hizo suyo como forma de vida, como comportamiento y como ideología, ya que, a pesar de su ascendencia aristocrática, prefirió vivir al margen de ese mundo social tan poderoso en toda España pero más aún en su Andalucía, y luchó por hacer su santa voluntad en numerosos aspectos de su existencia, tanto desde el punto de vista profesional, aunque no era muy avezado ni diestro para los negocios, como literario y particular e incluso familiar, al margen en este último caso de las convenciones sociales establecidas. Lo que pone de relieve su sentido liberal de rebeldía que impregna toda su obra y que da sentido a toda su poesía. Otro aspecto destacado por Issorel es el espiritualismo expresado en su obra, al margen desde luego a las creencias religiosas tradicionales, sino en busca de una ascensión hacia lo más alto tan íntima como de extrema complejidad, que dota a su poesía de una calidad indudable, bien patente desde luego en los poemas contenidos en esta completa antología.

\section{AUTORES}

\section{FRANCISCO JAVIER DÍEZ DE REVENGA}

Universidad de Murcia 